\title{
PENGARUH PEMBENTUKAN KARAKTER DISIPLIN DAN TANGGUNG JAWAB TERHADAP HASIL BELAJAR EKONOMI PERSAMAAN DASAR AKUNTANSI
}

\author{
Budiani dan Ni'matush Sholikhah \\ Universitas Negeri Surabaya \\ email: nididiani@gmail.com
}

\begin{abstract}
Abstrak: SMA Negeri 1 Gedangan Sidoarjo merupakan sekolah yang menerapkan pembentukan karakter pada setiap program sekolah. Program sekolah yang dijalankan di dalam kelas terintegrasi dengan mata pelajaran, termasuk mata pelajaran ekonomi. Proses pembelajaran ekonomi mengarahkan peserta didik untuk bisa disiplin dan bertanggung jawab akan pekerjaan yang diberikan. Tolok ukur keberhasilan mereka adalah hasil belajar yang diperlihatkan. Penelitian ini bertujuan menganalisis adanya pengaruh antara pembentukan karakter disiplin, dan pembentukan karakter bertanggung jawab terhadap hasil belajar ekonomi materi persamaan dasar akuntansi. Jenis penelitian ini kuantitatif model hubungan variabel ganda menggunakan dua variabel independen. Sampel yang digunakan berasal dari peserta didik kelas XII IIS SMA Negeri 1 Gedangan Sidoarjo berjumlah 85 responden. Pengumpulan data menggunakan observasi, studi Pustaka, dan kuesioner. Instrumen penelitian menggunakan skala likert. Uji hipotesis digunakan melalui uji t, uji $\mathrm{F}$, dan koefisien determinan atau $\mathrm{R}$ Square. Hasil penelitian menunjukkan adanya pengaruh positif dan signifikan secara parsial pembentukan karakter disiplin terhadap hasil belajar ekonomi materi persamaan dasar akuntansi. Ada pengaruh positif dan signifikan secara parsial pembentukan karakter bertanggung jawab terhadap hasil belajar ekonomi materi persamaan dasar akuntansi. Secara simultan pembentukan karakter disiplin dan bertanggung jawab berpengaruh signifikan terhadap hasil belajar ekonomi materi persamaan dasar akuntansi.
\end{abstract}

Kata kunci: pembentukan karakter, disiplin, tanggung jawab, hasil belajar ekonomi

\section{THE INFLUENCE OF CHARACTER BUILDING OF DISCIPLINE AND RESPONSIBILITY ON ECONOMIC LEARNING OUTCOMES OF ACCOUNTING BASIC EQUATION}

\begin{abstract}
SMA Negeri 1 Gedangan Sidoarjo is a school that implements character building in every school program. School programs that are run in the classroom are integrated with subjects, including economics. The economic learning process directs students to be able to be disciplined and responsible for the work provided. The benchmarks of their success are the learning outcomes shown. This study aims to analyze the influence between the formation of disciplinary characters, and the formation of characters responsible for economic learning outcomes of basic accounting equality material. This type of research is a quantitative dual variable relationship model using two independent variables. The sample used came from students of class XII IIS of SMA Negeri 1 Gedangan Sidoarjo totaling 85 respondents. Data collection used observation, literature study, and questionnaires. The research instrument uses a Likert scale. Hypothesis testing was used through $\mathrm{t}$ test, $\mathrm{F}$ test, and determinant coefficient or R Square. The result showed that there was a positive and partially significant influence on the formation of the disciplinary character on the economic learning outcomes of basic accounting equation material. There was a positive and partially significant influence on the formation of the characters responsible for the economic learning outcomes of the basic accounting equation material. Simultaneously the formation of disciplined and responsible character has a significant effect on the learning outcomes of economics in the basic accounting equation.
\end{abstract}

Keywords: character, discipline, responsibility, economic learning outcomes

\section{PENDAHULUAN}

Proses pendidikan berlangsung di lingkungan sekitar yang menyangkut peni- laian terhadap tujuan, isi, strategi, dan sarana pendidikan. Penilaian proses pembelajaran berkaitan dengan guru, kegiatan 
peserta didik, interaksi, dan program pembelajaran. Penilaian yang dilakukan melalui kajian komponen pendidikan adalah suatu umpan balik yang diberikan guru terhadap hasil pencapaian peserta didik dengan kriteria tertentu. Menurut Assahary, Barlian, \& Nurdin, (2017) bahwa penilaian merupakan proses yang berkesinambungan untuk mengumpulkan informasi tentang hasil belajar peserta didik yang bertujuan membuat keputusan berdasar kriteria. Penilaian dilakukan untuk menjabarkan kemampuan belajar peserta didik sehingga mengetahui kelebihan dan kekurangan bakat peserta didik dalam setiap bidang studi.

Pembelajaran bidang studi ekonomi memiliki cara belajar yang kompleks mulai dari metode menghafal, mencoba, hingga mengkreasi. Pada materi persamaan dasar akuntansi kelas XII IIS SMA Negeri 1 Gedangan Sidoarjo, peserta didik diharuskan menghafal definisi, dan fungsi akuntansi untuk bisa melanjutkan ke tahap selanjutnya. Kegiatan pembelajaran yang sudah berlangsung, peserta didik cukup aktif merespon materi yang disampaikan. Sebanyak $80 \%$ peserta didik melakukan interaksi dengan guru sebagai umpan balik atas pemberian materi. Namun, pada saat diberikan latihan soal, hanya sebanyak $40 \%$ peserta didik yang bisa mengerjakan dengan lancar, $40 \%$ lainnya masih mengalami kendala dan sering bertanya kepada guru, dan sisanya sebanyak $20 \%$ mengaku tidak bisa dan susah memahami. Melihat hasil awal penilaian, guru melakukan latihan soal secara berulang-ulang kepada peserta didik. Pada pertemuan ketiga sebanyak $80 \%$ peserta didik sudah mulai lancar mengklasifikasikan transaksi ke dalam kolom sehingga mendapat hasil yang benar pada saat melakukan penjumlahan dan $20 \%$ sisanya masih mengalami kendala.
Proses pembelajaran persamaan dasar akuntansi tidak hanya berfokus untuk memberikan materi juga membentuk karakter peserta didik, agar memiliki pembentukan karakter disiplin dan tanggung jawab dalam menjalankan tugasnya. Pembentukan karakter peserta didik diiringi dengan perubahan perilaku. Sekolah melakukan upaya pemberian pendidikan karakter melalui program sekolah. Peneliti melihat SMA Negeri 1 Gedangan Sidoarjo sangat baik dalam mengembangkan karakter peserta didik. Hal ini terlihat pada program sekolah yang terlaksana dengan lancar. Seperti pada saat upacara bendera sekitar $90 \%$ peserta didik mengikuti upacara dengan baik, 10\% lainnya datang terlambat ataupun tidak memakai atribut dengan lengkap. Hal lain nampak saat salat zuhur, secara bergantian peserta didik melakukan salat zuhur berjamaah di masjid sekolah pada jam istirahat kedua. Tujuan pemberian pendidikan karakter selain ingin memperbaikisikap peserta didikjuga ingin memperbaiki hasil belajar peserta didik dan membantu peserta didik mengatasi masalah yang dihadapi melalui interaksi yang baik dengan guru.

Pada dasarnya hasil belajar adalah akibat dari kegiatan belajar. Menurut Sudjana (1989). Hakikat hasil belajar merupakan pembenahan peilaku dalam aspek kognitif, afektif, dan psikomotor. Pemberian nilai memperhatikan tujuan agar sesuai yang diinginkan pendidik sebagai dasar penilaian. Klasifikasi hasil belajar yang dari Benyamin Bloom terdiri atas tiga ranah, yakni kognitif, afektif, dan psikomotor. Ketiga ranah tersebut digunakan dalam penilaian hasil belajar peserta didik di sekolah, dan diterapkan di seluruh mata pelajaran. Pada mata pelajaran ekonomi, penilaian ranah kognitif terjadi pada saat materi yang berkenaan dengan definisi, fungsi, tujuan, ser- 
ta klasifikasi. Penilaian ranah afektif terjadi pada saat aplikasi materi seperti mencoba menghitung di papan tulis maupun di lembar kerja siswa (LKS). Lalu ranah psikomotor terjadi pada saat menunjukkan keterampilan peserta didik, misalnya pada saat presentasi atau membuat produk.

Landasan konseptual filosofi pendidikan yang membebaskan adalah bersedia menghadapi era selanjutnya dengan mempelajari perkembangan teknologi dan ilmu pengetahuan. Pasal 3 Undang-Undang Nomor 20 Tahun 2003 tentang Sistem Pendidikan Nasional menyatakan tujuan dari pendidikan nasional yaitu pengembangan bakat peserta didik menjadi insan dengan iman serta takwa kepada Tuhan Yang Maha Esa, memiliki perilaku baik, sehat, cerdas, tanggap, dan memiliki gagasan baru guna hidup berbangsa dan bernegara. Memperkuat landasan sebelumnya menggunakan Peraturan Presiden Republik Indonesia Nomor 87 Tahun 2017 tentang Penguatan Pendidikan Karakter, menciptakan bangsa yang memiliki budaya yang memperkuat nilai. Karakter adalah cara berpikir yang dituangkan dalam tindakan untuk mendapatkan kesejahteraan hidup dengan baik di lingkungan keluarga maupun masyarakat.

Teori pendidikan karakter milik Lickona (2012) menegaskan bahwa karakter yang baik dimulai dari mengetahui, menginginkan, dan melakukan kebaikan di keseharian melalui sudut pandang menganalisis, kebiasaan berprasangka dan perilaku. Sekolah yang akan menerapkan pendidikan moral harus yakin bahwa nilai yang akan diberikan pada saat peserta didik bersekolah ada maksud baik untuk memperbaiki pribadi peserta didik sehingga nantinya menjadi masyarakat yang bersosialisasi. Hal ini didukung teori perilaku terencana atau Theory of Planned Behavior yang dikemukakan oleh Fishbein \& Ajzen
(1975). Perilaku yang terencana ini didasarkan pada aspek psikologi yang mendukung terjadinya perilaku.

Menurut Riyanti (2015) Theory of Planned Behavior diperlukan untuk mengukur kesinambungan antara sikap, perilaku, dan keyakinan terhadap perwujudan perilaku dapat mempengaruhi perilaku secara langsung. Menurut Yu, Shek, dan Zhu (Rafsanjani, Sholikhah, \& Prakoso, 2019) menyatakan bahwa ada tiga kondisi yang mendukung keterlaksanaan pendidikan umum, yaitu: (1) pembentukan perilaku yang mengembangkan kecerdasan berpikir (karakter) harus lebih besar daripada mengembangkan keterampilan; (2) membangun lingkungan yang mendukung pembentukan karakter peserta didik dan terintegrasi dalam pendidikan; dan (3) membangun komunikasi yang baik di antara pihak sekolah dan peserta didik baik di dalam kelas maupun di luar kelas. Pengondisian tersebut membuat peserta didik berkarakter baik sehingga berdampak pada intelektual peserta didik. Seni \& Ratnadi (2017) menyatakan bahwa individu berperilaku dipengaruhi oleh keyakinan sebagai bentuk ramalan atas konsekuensi yang diterima.

Mata pelajaran ekonomi merupakan mata pelajaran wajib jurusan ilmu sosial yang menerapkan sikap disiplin sebagai dasar dalam pembelajaran. Menurut Emile Durkeheim (Lickona, 2012) bahwa disiplin merupakan sisi moral dalam sebuah kelas dan sebagai bagian dari masyarakat kecil. Disiplin merupakan sebuah kesempatan yang memungkinkan untuk diterapkan di kelas dan berguna untuk mengendalikan peserta didik. Beberapa hasil penelitian menunjukkan bahwa pembentukan karakter disiplin berpengaruh terhadap hasil belajar, seperti pada penelitian Najib \& Achadiyah (2015), Mulyani (2016), Benninga, 
Berkorwitz, Kuehn, et al. (2003), Setiawan (2013), Kosim (2011), dan Laksana (2015). Selain karakter disiplin, karakter tanggung jawab juga diperlukan peserta didik untuk menuntun pemenuhan kewajiban. Peran guru sebagai pengendali disiplin perlu memberikan latihan disiplin moral, antara lain: (1) merencanakan kebijakan; (2) pembiasaan kedisiplinan; (3) melakukan tanggung jawab; dan (4) rasa peduli kepada masalah.

Tanggung jawab merupakan kemampuan menyelesaikan tugas hingga mendapatkan hasil yang diinginkan seperti mengerjakan tugas, mendengarkan guru saat jam pelajaran. Menurut Lickona (2012) perilaku peduli yang ditunjukkan merupakan tanggung jawab yang bermakna menjalankan kewajiban dengan sungguh-sungguh lalu mengupayakan hasil terbaik. Beberapa penelitian menunjukkan bahwa pembentukan karakter tanggung jawab berpengaruh terhadap hasil belajar, seperti pada penelitian Mihardi, Sabani, \& Derlina (2015), Derlina, Mihardi, \& Sabani (2016a), Derlina, Mihardi, \& Sabani (2016b), Setiawan (2013), dan Kosim (2011).

Melihatadanya kesinambungan yang baik di antara pemberian karakter kepada peserta didik dengan hasil belajar yang diperoleh, maka peneliti melakukan penelitian yang berkenaan dengan pembentukan karakter disiplin dengan indikator variabel antara lain: peserta didik datang tepat waktu, berdoa sebelum memulai pembelajaran, mengenakan seragam sesuai peraturan sekolah, menggunakan kelengkapan atribut sekolah, membawa alat tulis sekolah, menciptakan suasana kondusif di dalam kelas. Pembentukan karakter tanggung jawab juga memiliki indikator variabel sebagai kriteria pengukuran, antara lain: peserta didik mengumpulkan tugas yang diberikan oleh guru, mengikuti seluruh ujian yang dilak- sanakan oleh sekolah, peserta didik merawat peralatan di dalam kelas, menjaga kebersihan di dalam kelas, dan menjaga keamanan di dalam kelas. Hasil belajar yang digunakan adalah hasil ulangan harian KD 3.2 dan 4.2 materi persamaan dasar akuntansi.

Berdasarkan latar belakang dan kajian teori di atas, dipandang perlu melakukan penelitian tentang pengaruh pembentukan karakter disiplin dan tanggung jawab terhadap hasil belajar ekonomi pada materi persamaan dasar akuntansi di SMA Negeri 1 Gedangan Sidoarjo. Tujuan dilaksanakannya penelitian ini adalah untuk menganalisis adanya pengaruh pembentukan karakter disiplin terhadap hasil belajar ekonomi materi persamaan dasar akuntansi, menganalisis adanya pengaruh pembentukan karakter bertanggung jawab terhadap hasil belajar ekonomi materi persamaan dasar akuntansi, dan menganalisis adanya pengaruh secara simultan pembentukan karakter disiplin dan bertanggung jawab terhadap hasil belajar ekonomi materi persamaan dasar akuntansi SMA Negeri 1 Gedangan Sidoarjo.

\section{METODE}

Penelitian ini menggunakan pendekatan kuantitatif berupa hubungan variabel ganda. Instrumen yang digunakan adalah kuesioner skala likert. Pernyataan dalam kuesioner atau angket menggunakan pernyataan yang bersifat positif. Penelitian ini juga menggunakan data primer yang didapatkan dari angket dan observasi secara langsung. Populasi penelitian ini 108 peserta didik. Penentuan sampel menggunakan probability sampling jenis simple random sampling dan diperoleh sampel sebesar 85 peserta didik. Penelitian dilakukan pada bulan Juni 2020 dan dilakukan secara online yakni dengan mengirimkan alamat link 
kepada peserta didik untuk dapat mengisi angket. Variabel penelitian ini yaitu disiplin dan tanggung jawab.

Pengumpulan data menggunakan teknik observasi, studi pustaka, dan kuesioner. Sedangkan analisis data menggunakan analisis statistik deskriptif. Tahapan yang harus dipenuhi antara lain: transformasi data, validitas, reliabilitas, serta uji asumsi klasik dan independen. Penelitian ini menggunakan rumusan masalah asosiatif dengan hubungan simetris. Data penelitian berjenis kualitatif dan kuantitatif. Data kualitatif diperoleh dengan teknik observasi kemudian diuraikan dalam bentuk catatan lapangan. Data kuantitatif diperoleh dengan kuesioner. Transformasi data pada penelitian ini menggunakan aplikasi Soland 2.1 untuk mendapatkan data interval agar data tidak bias. Uji asumsi klasi dan uji hipotesis dilakukan dengan aplikasi SPSS 21. Uji asumsi klasik dengan 5 syarat pengujian, yaitu uji normalitas, uji autokorelasi, uji heterokedastisitas, dan uji multikolinieritas. Uji hipotesis digunakan untuk melihat adanya pengaruh variabel bebas terhadap variabel terikat melalui uji $t$, uji $F$, dan koefisien determinan atau $\mathrm{R}$ Square.

\section{HASIL DAN PEMBAHASAN}

Datayang telah diperoleh dipergunakan untuk menganalisis pengaruh pembentukan karakter disiplin dan bertanggung jawab terhadap hasil belajar ekonomi khususnya materi persamaan dasar akuntansi. Data diambil dengan cara kuesioner online dari 85 responden yang berasal dari peserta didik kelas XII IIS 1, kelas XII IIS 2, dan kelas XII IIS 3 SMA Negeri 1 Gedangan Sidoarjo. Kuesioner menggunakan skala likert sebagai alat mengukur dengan skor 1-5. Penelitian ini mengguanakan 2 variabel bebas dengan 11 indikator. Variabel pertama adalah disiplin dengan 6 indi- kator pertanyaan dan jumlah pertanyaan 16 butir. Variabel kedua adalah bertanggung jawab dengan 5 indikator pertanyaan dan jumlah pertanyaan 17 butir. Dengan demikian, total pertanyaan menjadi 33 butir. Responden yang mengisi kuesioner penelitian ini memiliki karakteristik memiliki bekal pendidikan karakter disiplin dan bertanggung jawab dari sekolah, background responden diacuhkan dalam model. Adapun klasifikasi jumlah responden dapat dilihat pada Tabel 1 berikut.

\section{Tabel 1. Klasifikasi Responden}

\begin{tabular}{lll}
\hline Kelas & Frekuensi & Prosentase \\
\hline XII IIS 1 & 29 & $34.1 \%$ \\
XII IIS 2 & 28 & $32.9 \%$ \\
XII IIS 3 & 28 & $32.9 \%$ \\
\hline
\end{tabular}

Berdasarkan Tabel 1 diketahui jumlah responden 85 peserta didik yang diambil secara acak dari tiga kelas jurusan IIS. Terlihat dari data tabel bahwa kelas XII IIS 1 lebih banyak respondennya 1 poin di antara yang lainnya. Pada proses validitas data, 33 butir pertanyaan dinyatakan valid dengan nilai signifikansi $<0.05$, dengan rata-rata jawaban responden bernilai 3, yang artinya responden masih kurang sering dalam melakukan kegiatan-kegiatan di sekolah yang dapat membangun pembentukan karakter disiplin dan tanggung jawab mereka. Perlu pembiasaan pendidikan karakter di sekolah dengan intensitas waktu lebih banyak dan lingkungan yang mendukung. Pada indikator pembentukan karakter disiplin dengan total 16 pertanyaan dihasilkan nilai rata-rata sebesar \pm 3 yang artinya kecenderungan peserta didik menjawab kadang-kadang. Pada indikator pembentukan karakter bertanggung jawab dengan total 17 pertanyaan juga dihasilkan nilai rata-rata nya sebesar \pm 3 yang artinya bahwa peserta didik juga cenderung jarang 
melakukan kegiatan-kegiatan yang bertanggung jawab dalam kegiatan di sekolah.

Dengan uji reliabilitas menggunakan Cronbach Alpha diketahui hasil pembentukan karakter disiplin sebesar $0.730>0,7$ dan hasil pembentukan karakter tanggung jawab sebesar $0.749>0.7$. Dengan demikian, hasil penelitian dapat dinyatakan reliabel. Uji asumsi klasik yang dilakukan terdapat 5 uji yang digunakan, yaitu uji normalitas, uji autokorelasi, uji heteroskedastisitas, uji linieritas, dan uji multikolinieritas. Uji normalitas menggunakan metode Kolmogorov-Smirnov dengan hasil nilai Asymp.Sig sebesar $0.300>0.05$, yang dapat dikatakan lolos uji normalitas dan data terdistribusi normal. Uji autokorelasi menggunakan metode uji D-W dengan nilai yang diperoleh sebesar 0.268 dan dapat diketahui nilai dL sebesar 1.600, dU sebesar 1.696, 4- dU sebesar 2.304, dan 4-dL sebesar 2.4, yang berarti dinyatakan tidak lolos uji autokorelasi, karena terletak di daerah positif autokorelasi. Menurut Gujarati (2003) bahwa autokorelasi yang timbul pada regresi linier menggunakan pendekatan Ordinary Least Square (OLS) dapat ditekan dengan metode Generalized Least Squares (GLS) dengan sifat Random Effect karena jumlah waktu lebih kecil dari jumlah responden yang digunakan. Penelitian yang dilakukan saat ini memiliki kriteria yang sama, yakni jenis penelitiannya Cross Section.

Uji heteroskedastisitas menggunakan metode uji Glejser, diperoleh nilai signifikansi pada uji glejser variabel disiplin sebesar $0.739>0.05$ dan bertanggung jawab sebesar $0.132>0.05$. Dengan demikian, dinyatakan bahwa pada data tidak terjadi heteroskedastisitas, yang artinya varian residual bersifat homokedastisitas.

Ujimultikoliniertas menggunakan metode nilai Tolerance dan VIF dengan kriteria nilai Tolerance $>0.1$ dan nilai VIF $<10$ maka H0 diterima. Jadi, diketahui bahwa pembentukan karakter disiplin dan bertanggung jawab sama-sama memiliki nilai Tolerance sebesar $0.327>0.1$ dan nilai VIF sebesar $3.057<10$. Dengan dimikian, dapat dinyatakan tidak terjadi hubungan linier antara kedua variabel. Uji linieritas menggunakan metode Test For Linierity, diketahui bahwa nilai linierity $\mathrm{F}$ sebesar $17.546>$ 0.05 dengan sig. 0.008 dengan demikian dinyatakan lolos uji linieritas. Berdasarkan uji koefisien determinasi diketahui nilai Adj R-Square sebesar 0.331, artinya variabel pembentukan karakter disiplin dan bertanggung jawab mempengaruhi hasil belajar ekonomi materi akuntansi sebesar 33.1\% dan sisanya $66.9 \%$ dipengaruhi oleh variabel lain diluar model.

Uji hipotesis dilakukan sebagai bentuk pembuktian hipotesis berdasarkan hasil penelitian penelitian. Berdasarkan hasil uji $\mathrm{t}$ statistik pembentukan karakter disiplin diperoleh nilai thitung $>$ ttabel sebesar $2.335>1.664$ dan memiliki nilai signifikansi sebesar $0.039<0.05$. Dengan demikian, dinyatakan pembentukan karakter disiplin berpengaruh positif dan signifikan secara parsial terhadap hasil belajar ekonomi materi persamaan dasar akuntansi.

Berdasarkan hasil uji $\mathrm{t}$ statistik pembentukan karakter bertanggung jawab diperoleh nilai thitung $>$ ttabel sebesar 1.520 $<1.664$ dan memiliki nilai signifikansi sebesar $0.032<0.05$. Dengan demikian, dinyatakan pembentukan karakter bertanggung jawab berpengaruh positif dan signifikan secara parsial terhadap hasil belajar ekonomi materi persamaan dasar akuntansi.

Berdasarkan hasil uji F statistik diperoleh nilai Fhitung > Ftabel sebesar $4.979>$ 3.957 dan memiliki nilai signifikansi sebesar $0.009<0.05$. Dengan demikian, dinyata- 
kan bahwa pembentukan karakter disiplin dan bertanggung jawab secara simultan berpengaruh signifikan terhadap hasil belajar ekonomi materi persamaan dasar akuntansi SMA Negeri 1 Gedangan Sidoarjo.

Penggunaan variabel dalam penelitian ini dianggap penting karena banyak faktor yang mempengaruhi karakter yang ditanamkan di sekolah. Kedua karakter ini yang diutamakan. Hal ini tercermin dari program yang diadakan oleh sekolah untuk membuat peserta didik memiliki karakter disiplin dan bertanggung jawab. Selaras dengan ini, Ramdhani (2011) menyatakan bahwa kontrol perilaku yang dilakukan akan memperbaiki individu dengan dukungan lingkungan sekitar. Penelitian Rafsanjani, et al. (2019) juga mendukung hasil ini dengan menyatakan bahwa pemberian bekal karakter kepada peserta didik berdampak pada perubahan kecerdasan intelektual sehingga perilaku peserta didik dapat dikontrol. Berdasarkan hal ini tercermin bahwa kontrol perilaku yang dilakukan oleh pihak sekolah dengan membentuk karakter disiplin dan bertanggung jawab akan memperbaiki sikap peserta didik yang didukung oleh peran serta guru dan warga sekolah lainnya.

\section{Pengaruh Pembentukan Karakter Disi- plin terhadap Hasil Belajar Ekonomi Ma- teri Persamaan Dasar Akuntansi}

Hasil analisis penelitian menunjukkan bahwa pembentukan karakter disiplin berpengaruh positif dan signifikan terhadap hasil belajar ekonomi pada materi persamaan dasar akuntansi. Disiplin menjadikan alasan bagi peserta didik untuk menaati peraturan sekolah sebagai bentuk tanggung jawab dalam segi pendidikan seperti memberi batasan, mencegah penyimpangan, dan mengembangkan perilaku peserta didik. Mampu menjelaskan kemampuan peserta didik selama proses pembelajaran sehingga orang tua dapat mengoreksi kekurangan dari tipe belajar anaknya, diharapkan bisa mengatasi kesulitan belajar peserta didik. Dengan demikian, dapat diketahui bahwa pembentukan karakter disiplinmerupakan faktor penting untuk memperoleh hasil belajar yang baik, sehingga diperlukan untuk diterapkan pada mata pelajaran ekonomi dan juga mata pelajaran lain yang ada di sekolah.

\section{Pengaruh Pembentukan Karakter Bertang- gung Jawab Terhadap Hasil}

Menurut Najib \& Achadiyah (2015) bahwasannya peserta didik dengan karakter disiplin akan menaati peraturan yang dibuat oleh pihak sekolah, mengikuti pembelajaran yang ada di kelas, tidak membolos pada saat jam pelajaran, dan menciptakan suasana kondusif di dalam kelas. Dengan cara ini, peserta didik akan lebih berprestasi, karena tidak ada pelajaran yang tertinggal. Pada saat peserta didik menjadi disiplin, ia akan mendengarkan semua arahan dan penjelasan dari guru, sehingga pada saat mengerjakan tugasia mampu menuntaskannya. Hal ini menandakan bahwa peserta didik telah mengubah cara pandangnya dalam pendidikan. Selaras dengan ini, AAC \& U (Rafsanjani et al., 2019) mengatakan bahwa peserta didik yang memiliki kecerdasan intelektual, keterampilan, dan kemampuan analisis dalam memecahkan masalah akan lebih mudah menerapkan ilmunya ke dalam kehidupan sehari-hari.

Kesinambungan karakter disiplin dalam hasil belajar tercermin dalam fungsi hasil belajar yang mengharuskan guru membuat laporan kemajuan prestasi peserta didik untuk orang tua pada setiap periode. 


\section{Belajar Ekonomi Materi Persamaan Dasar} Akuntansi

Hasil analisis penelitian menunjukkan bahwa pembentukan karakter bertanggung jawab berpengaruh signifikan dan positif terhadap hasil belajar ekonomi materi persamaan dasar akuntansi. Tanggung jawab perlu dibuktikan melalui cara yang relevan untuk mendukung individu lain, meringankan beban, dan membuat keadaan lebih baik. Menurut Rafsanjani et al. (2019) bahwa proses pembelajaran yang menggunakan pendekatan karakter membangun peserta didik yang mandiri sehingga mampu bertanggung jawab atas kewajibannya. Pada pembelajaran ekonomi peserta didik dituntun bertanggung jawab atas kewajiban yang harus dipenuhi seperti mengerjakan tugas, dan mendengarkan guru saat jam pelajaran. Tanggung jawab pada guru dimulai pada pemenuhan pemaparan materi, pemberian tugas, nilai kepada peserta didik, dan datang tepat waktu. Semua hal tersebut dilakukan guru agar dapat mencapai tujuan pembelajaran sesuai yang direncanakan. Derlina, et al. (2016a) menyatakan bahwa karakter tanggung jawab akan meningkat apabila dalam proses pembelajaran peserta didik memulai dan mengakhiri pelajaran dengan baik.

Adanya karakter tanggung jawab menjadikan peserta didik mau melakukan eksperimen, observasi, serta melaksanakan tugas dan kewajibannya sesuai prosedur yang ditentukan untuk mendapat hasil belajar yang baik. Karakter bertanggung jawab terlihat dalam karakter interpersonal. Artinya, untuk mengembangkan karakter tersebut diperlukan orang lain sebagai pemegang kendali atau kontrol agar komunikasi dapat berjalan dengan baik. Kesinambungan karakter bertanggung jawab dengan hasil belajar dilihat dari fungsi hasil belajar yakni mengetahui tercapainya tuju- an pengajaran. Sikap peserta didik yang mengumpulkan tugas dan mengikuti ujian secara rutin akan membantu guru dalam memantau pihak orang tua. Tanggung jawab dan disiplin harus dilakukan diri sendiri dan atas kemauan sendiri untuk kebaikan diri sendiri, harus tertib, dan patuh terhadap aturan yang berlaku.

Pada dasarnya pembentukan karakter harus dikembangkan dari lingkungan keluarga, sekolah, hingga masyarakat luas secara berkesinambungan. Proses pengembangan nilai karakter juga harus digunakan pada semua mata pelajaran di sekolah. Semua komponen harus terlibat dalam penerapan pembentukan karakter keberhasilan proses pembelajaran sehingga dapat menentukan langkah selanjutnya dalam memperbaiki kegiatan pembelajaran. Oleh sebab itu, pembentukan karakter bertanggung jawab menjadi faktor penting memperoleh hasil belajar yang baik sehingga diperlukan untuk diterapkan pada pelajaran ekonomi dan juga semua mata pelajaran yang ada di sekolah.

\section{Pengaruh Pembentukan Karakter Disiplin} dan Bertanggung Jawab terhadap Hasil Belajar Ekonomi Materi Persamaan Dasar Akuntansi

Dari kedua hasil penelitian antarvariabel sebelumnya yang telah dibahas secara parsial, secara bersama-sama pembentukan karakter disiplin dan bertanggung jawab berpengaruh signifikan terhadap hasil belajar ekonomi materi persamaan dasar akuntansi. Hasil penelitian ini sesuai dengan penelitian Setiawan (2013), Laksana (2015), dan Kosim (2011) yang menyatakan bahwa karakter disiplin dan bertanggung jawab berpengaruh positif dan signifikan terhadap hasil belajar. Nilainilai tersebut harus ditanamkan kepada peserta didik sejak dini. Penanaman nilai ka- 
rakter harus dilakukan secara berkelanjutan dan dengan kontrol tanpa pamrih. Pembentukan karakter pada saat di sekolah akan menjadikan sebuah kriteria bagi sekolah, yakni terbentuknya budaya sekolah yang akhirnya menjadi ciri khas sekolah tersebut. Peserta didik tidak hanya menerapkan perilaku dengan karakter disiplin dan tanggung jawab pada saat di sekolah, namun pada saat di luar sekolah juga. Menurut Lickona (2012) lingkungan yang mendukung pembentukan karakter peserta didik akan mempermudah peserta didik dalam penerapan karakter disiplin dan bertanggung jawab. Beberapa aspek yang dimungkinkan menjamin untuk terbentuknya karakter dengan baik dalam diri seseorang antara lain: (1) hati nurani; (2) harga diri; (3) empati; (4) mencintai kebaikan; (5) kendali diri; dan (6) kerendahan hati. Pembentukan karakter disiplin dan bertanggung jawab yang dilakukan perlu adanya rancangan yang dibuat oleh pihak sekolah agar selalu terintegrasi dengan proses pembelajaran sehingga nantinya mampu memenuhi prinsip penilaian hasil belajar. Penilaian yang dilakukan memerlukan luaran yang objektif agar dapat menggambarkan kemampuan peserta didik dan harus mencakup aspek kognitif, afektif, dan psikomotor.

\section{SIMPULAN}

Berdasarkan hasil penelitian dan pembahasan yang telah diuraikan sebelumnya, dapat disimpulkan hal-hal seperti berikut. (1) Secara parsial terdapat pengaruh positif dan signifikan pembentukan karakter disiplin terhadap hasil belajar ekonomi materi persamaan dasar akuntansi SMA Negeri 1 Gedangan Sidoarjo. (2) Secara parsial terdapat pengaruh positif dan signifikan pembentukan karaktekter bertanggung jawab terhadap hasil belajar ekonomi materi persamaan dasar akuntansi SMA Negeri 1 Gedangan Sidoarjo. (3) Secara simultan terdapat pengaruh posistif dan signifikan pembentukan karakter disiplin dan bertanggung jawab terhadap hasil belajar ekonomi materi persamaan dasar akuntansi SMA Negeri 1 Gedangan Sidoarjo. Dengan demikian, pembentukan karakter disiplin dan tanggung jawab sangat penting dilakukan oleh sekolah, terutama guru, untuk peningkatan hasil belajar siswa dalam mata pelajaran ekonomi dan juga mata pelajaran yang lain.

Guru sebagai mediator pembentukan karakter peserta didik diharapkan lebih banyak memberikan teladan dalam berdisiplin dan bertanggung jawab agar peserta didik termotivasi untuk menirunya. Pembentukan karakter pada peserta didik harus dilakukan oleh semua pihak di sekolah, agar tidak terjadi ketimpangan dalam mengajarkan karakter disiplin dan bertanggung jawab secara baik.

\section{UCAPAN TERIMA KASIH}

Penulis ingin mengucapkan terima kasih kepada pihak-pihak yang telah memberi bantuan demi selesainya tulisan ini, terutama kepada para anggota dewan penyunting Jurnal Pendidikan Karakter yang banyak memberikan masukan dan koreksi sehingga tulisan ini layak dimuat di edisi sekarang ini.

\section{DAFTAR PUSTAKA}

Assahary, S., Barlian, E., \& Nurdin, S. (2017). The development of thematic learning model to improve students ' character in an integrated learning of religion education and environment towards students in Adiwiyata school. International Journal of Multicultural and Multireligious Understanding, 4(6), 1-15. DOI: 10.18415 /ijmmu.v4i6.95. 
Benninga, J.S., Berkorwitz, M.W., Kuehn, P., \& Smith, K. (2003). The relationship of character education implementation and academic achievement in elementary school. Journal of Research in Character Education, 1(1), 1932. Retrieved from https://www.semanticscholar.org/paper/THE-RELATIONSHIP-OF-CHARACTEREDUCATION-AND-IN-BenningaBerkowitz/5d257ee932a311d4defe324 04d71c3a578eb3842.

Derlina, Mihardi, S., \& Sabani. (2016a). The effectiveness of learning model based character education in increasing student. Proceedings of the 1st Annual International Seminar on Transformative Education and Educational Leadership (AISTEEL), 151-157. Retrieved from http://aisteel.unimed.ac.id/proceedi ng-aisteel-2016.

Derlina, Mihardi, S., \& Sabani. (2016b). The influence of learning model based character education to student characters and learning outcomes. Advances in Social Sciences Research Journal, 3(11), 135-140. DOI: https://doi.org/10.14738/assrj.311.2293.

Fishbein, M., \& Ajzen, I. (1975). Belief, Attitude, Intention And Behavior (An introduction to theory and research). Retrieved from https://people.umass.edu/aizen/f\&a1975.html.

Gujarati, D.N. (2003). Ekonometrika dasar. Jakarta: Salemba Empat.

Kosim, M. (2011). Urgensi pendidikan karakter. Karsa, 91(1), 86-92. Retrieved from http:/ / ejournal.iainmadura.ac.id/karsa/article/view/78/70.
Laksana, S.D. (2015). Urgensi pendidikan karakter bangsa di sekolah. Muaddib, 5(1), 167-184. Retrieved from http:/ /journal.umpo.ac.id/index.php/muad dib/article/view/67/61.

Lickona, T. (2012). Educating for character: Mendidik untuk membentuk karakter. Terjemahan Juma Wadu Wamaungu. Jakarta: Bumi Aksara.

Mihardi, S., Sabani, \& Derlina. (2015). Improved characters and student learning outcomes through development of character education based general physics learning model. Journal of Education and Practice, 6(21), 162-171. Retrieved from http://digilib.unimed.ac.id/id/eprint/22421.

Mulyani, A. (2016). Pengaruh pendidikan karakter terhadap hasil belajar siswa dalam mata pelajaran sejarah kelas XI IIS di SMA Negeri I Wonoayu, Sidoarjo. AVATARA, e-Journal Pendidikan Sejarah, 4(2), 320-328. Retrieved from https://jurnalmahasiswa.unesa.ac.id/index.php/avatara/article/ view/14668/13316.

Najib, A., \& Achadiyah, B.N. (2015). Pengaruh pendidikan karakter terhadap prestasi belajar siswa. Jurnal Ekonomi Dan Pendidikan, 9(1), 102-109. DOI: https://doi.org/10.21831/jep.v9i1.41 48.

Peraturan Presiden Republik Indonesia Nomor 87 Tahun 2017 tentang Penguatan Pendidikan Karakter.

Rafsanjani, M.A., Ni'matush Sholikhah, \& Prakoso, A.F. (2019). Does the "Idaman Jelita" character of Universitas Negeri Surabaya influence students economics literacy? Dinamika Pendi- 
dikan, 14(2), 205-215. DOI: https://doi.org/10.15294/dp.v14i2.22214.

Ramdhani, N. (2011). Penyusunan alat pengukur berbasis theory of planned behavior. Buletin Psikologi, 19(2), 5569. DOI: 10.22146/bpsi.11557.

Riyanti. (2015). Intensi mencontek ditinjau dari theory of planned behavior. Jurnal Ilmiah Psikologi Terapan, 03(02), 249-267. DOI: https:// doi.org/10.22219/jipt.v3i2.3531.

Seni, N.N.A., \& Ratnadi, N.M.D. (2017). Theory of planned behavior untuk memprediksi niat berinvestasi. Ejurnal Ekonomi dan Bisnis, 6(12), 40434068. DOI: https://doi.org/10.24843/EEB.2017.v06.i12.p01.
Setiawan, D. (2013). Peran pendidikan karakter dalam mengembangkan kecerdasan moral. Jurnal Pendidikan Karakter, 3(1), 53-63. DOI: https:// doi.org/10.21831/jpk.v0i1.1287.

Sudjana, N. (1989). Penilaian hasil proses belajar mengajar. Bandung: PT Remaja Rosdakarya.

Undang-Undang Republik Indonesia Nomor 20 Tahun 2003 Tentang Sistem Pendidikan Nasional. 